\title{
Wiek naczyń — u kogo i jak go oceniać? Czy możemy "odmłodzić" naczynia naszych pacjentów?
}

Vascular age - in whom and how to evaluate it? Can we "rejuvenate" the vessels of our patients?

\section{Agata Tymińska, Agnieszka Kapłon-Cieślicka}

I Katedra i Klinika Kardiologii Warszawskiego Uniwersytetu Medycznego

\section{STRESZCZENIE}

Kluczową rolę w prewencji chorób układu sercowo-naczyniowego (CVD) odgrywa ocena całkowitego ryzyka sercowo-naczyniowego. Pozwala ona wyodrębnić pacjentów zagrożonych wystąpieniem CVD i zaplanować odpowiednie działania w celu ograniczenia lub eliminacji czynników ryzyka. Karta SCORE jest praktycznym narzędziem umożliwiającym oszacowanie 10-letniego ryzyka zgonu z powodu CVD. U młodych pacjentów, u których występują czynniki ryzyka, ryzyko bezwzględne wyliczone na podstawie karty SCORE może być jednak niskie mimo istotnie podwyższonego ryzyka względnego. W tej grupie chorych ocena tak zwanego wieku ryzyka sercowo-naczyniowego (inaczej: wieku serca, wieku naczyń) może być przydatna w identyfikacji osób, u których należy wdrożyć intensywne działania prewencyjne. Jednocześnie zastosowanie pojęcia „wiek ryzyka” ułatwia komunikację z pacjentem poprzez obrazowe przedstawienie mu oczekiwanego skrócenia długości życia w przypadku niepodjęcia działań prewencyjnych. Działania te powinny się koncentrować na ograniczeniu istniejących czynników ryzyka, co u części pacjentów będzie wymagać zastosowania farmakoterapii. Lekami o udowodnionej skuteczności w obniżaniu ryzyka CVD, także w ramach prewencji pierwotnej, są statyny.
Istotnie obniżają one stężenie lipoprotein o ma†ej gęstości, które mają kluczowe znaczenie dla rozwoju miażdżycy. Jednocześnie leki te wykazują pozalipidowe działania plejotropowe, dzięki czemu mogą zahamować lub nawet częściowo odwrócić niekorzystne zmiany w obrębie ściany naczyń i doprowadzić do obniżenia wieku ryzyka sercowo-naczyniowego.

Słowa kluczowe: choroby układu sercowo-naczyniowego, wiek ryzyka sercowo-naczyniowego, miażdżyca, prewencja pierwotna, statyna, atorwastatyna

\section{Choroby Serca i Naczyń 2019, 16 (2), 118-129}

\section{ABSTRACT}

Total cardiovascular risk assessment plays a key role in the prevention of cardiovascular disease (CVD). It facilitates identification of patients with increased CVD risk and allows to plan appropriate actions to reduce or eliminate risk factors. The SCORE chart is a practical tool for estimation of individual 10-year risk of fatal CVD. However, in young patients with risk factors, the absolute risk calculated with the SCORE chart may be low despite significantly elevated relative risk. In this group of patients, assessment of cardiovascular risk age (heart age, vascular age) may be useful for identification of individuals in whom intensive preventive measures should be implemented.

Adres do korespondencji:

dr hab. n. med. Agnieszka Kapłon-Cieślicka

I Katedra i Klinika Kardiologii

Warszawski Uniwersytet Medyczny

ul. Banacha 1a, 02-097 Warszawa

tel. 2259919 58, faks 225991957

e-mail: agnieszka.kaplon@gmail.com 
These measures should focus on reducing existing risk factors, which in some patients might require the use of pharmacotherapy. Statins were proven to be effective in CVD risk reduction, including primary prevention. Statins significantly lower concentrations of low-density lipoproteins, which are crucial for the development of atherosclerosis. Moreover, beyond their cholesterol-lowering properties, statins exert pleiotropic ef- fects, leading to inhibition or even partial reversal of unfavorable changes within the vessel wall, and to a reduction of cardiovascular risk age.

Key words: cardiovascular diseases, cardiovascular risk age, atherosclerosis, primary prevention, statin, atorvastatin

Choroby Serca i Naczyń 2019, 16 (2), 118-129

\section{WPROWADZENIE}

Choroby układu sercowo-naczyniowego (CVD, cardiovascular diseases) pozostają główną przyczyną zgonów na świecie [1, 2]. Nadrzędnym celem prewencji CVD jest zmniejszenie chorobowości i śmiertelności poprzez działania na poziomie populacyjnym lub ukierunkowanym na jednostkę promujące zdrowy styl życia, wczesną identyfikację pacjentów zagrożonych wystąpieniem CVD oraz ograniczenie czynników ryzyka [1]. Podkreśla się, że wczesne zmiany miażdżycowe w układzie tętniczym powstają już $\mathrm{w}$ dzieciństwie, a nawet $\mathrm{w}$ życiu płodowym [3]. Przewidywanie wystąpienia w przyszłości CVD u wyjściowo zdrowych osób pozostaje wyzwaniem we współczesnej medycynie. Wiek metrykalny jest niekwestionowanym, niepoddającym się modyfikacji czynnikiem ryzyka CVD [1]. Coraz więcej danych wskazuje jednak na to, że wiek biologiczny może być pod tym względem ważniejszy niż kalendarzowy. W 2012 roku w wytycznych Europejskiego Towarzystwa Kardiologicznego (ESC, European Society of Cardiology) dotyczących prewencji CVD po raz pierwszy wprowadzono pojęcie "wiek ryzyka sercowo-naczyniowego" (inaczej: wiek ryzyka, wiek serca, wiek naczyń [vascular age]) [2]. W najnowszym dokumencie ESC, opublikowanym w 2016 roku, utrzymano zalecenie dotyczące przeprowadzania oceny wieku ryzyka zwłaszcza u osób młodych [1].

\section{OCENA RYZYKA SERCOWO-NACZYNIOWEGO}

Zgodnie z aktualnymi wytycznymi ESC zaleca się, aby porady obejmujące modyfikację czynników ryzyka u osób bez jawnej CVD opierały się na ocenie całkowitego ryzyka sercowo-naczyniowego [1]. Dostępnych jest kilka skal oceny bezwzględnego ryzyka sercowo-naczyniowego. Najczęściej stosowane skale to Framingham Risk
Score w Stanach Zjednoczonych i SCORE (Systematic COronary Risk Evaluation) w Europie [4, 5]. Skale te są przeznaczone do stosowania $w$ ramach prewencji pierwotnej, czyli u chorych bez wcześniejszych incydentów sercowo-naczyniowych. Skala SCORE uwzględnia pięć podstawowych czynników ryzyka (wiek, płeć, palenie tytoniu, stężenie cholesterolu całkowitego i skurczowe ciśnienie tętnicze) oraz umożliwia oszacowanie 10-letniego ryzyka wystąpienia pierwszego zdarzenia sercowo-naczyniowego zakończonego zgonem [4]. Skala ta może być kalibrowana na podstawie danych dotyczących śmiertelności z powodu CVD w określonym czasie w danej populacji. Istnieją karty ryzyka SCORE skalibrowane oddzielnie dla krajów europejskich o niskim i oddzielnie dla krajów o wysokim ryzyku sercowo-naczyniowym (Polska należy do tej drugiej grupy). Ponadto dostępna jest wersja skali dostosowana do populacji polskiej (Pol-SCORE 2015) [6]. Na stronie www.heartscore.org możliwe jest korzystanie z elektronicznej karty SCORE prezentującej wyniki w sposób przejrzysty i zrozumiały dla pacjenta, także w języku polskim.

Skala ryzyka SCORE umożliwia przypisanie danej osoby do grupy niskiego $(<1 \%)$, umiarkowanego $(\geq 1 \%$ $\mathrm{i}<5 \%$ ), wysokiego $(\geq 5 \% \mathrm{i}<10 \%)$ oraz bardzo wysokiego $(\geq 10 \%)$ ryzyka zgonu z powodu CVD w ciągu najbliższych 10 lat. Pozwala to na identyfikację tych pacjentów, u których należy wdrożyć intensywniejsze postępowanie w zakresie modyfikacji czynników ryzyka (w tym u części farmakoterapię) w celu zmniejszenia zagrożenia zgonem sercowo-naczyniowym [7]. Problemem pozostaje jednak ocena ryzyka u obciążonych czynnikami ryzyka młodych pacjentów, u których stopień zagrożenia zgonem z powodu CVD w ciągu najbliższych 10 lat jest niski (SCORE < 1\%) z uwagi na wiek (jako że większość zdarzeń sercowo-naczyniowych występuje w później- 
szym okresie życia), mimo że ich ryzyko względne może być istotnie zwiększone i osoby te mogą wymagać intensywnych działań prewencyjnych. U tych pacjentów można:

- przeprowadzić ocenę ryzyka względnego (korzystając z karty ryzyka względnego [1] pokazującej, ile razy ryzyko osoby obciążonej czynnikami ryzyka jest wyższe niż ryzyko osoby w tym samym wieku i tej samej płci, ale bez czynników ryzyka);

- oszacować wiek ryzyka sercowo-naczyniowego (wiek serca, wiek naczyń): wiek ryzyka danej osoby obciążonej czynnikami ryzyka odpowiada wiekowi metrykalnemu osoby tej samej płci, ale bez czynników ryzyka lub z idealnie kontrolowanymi czynnikami ryzyka. Oszacowania wieku serca można dokonać orientacyjnie za pomocą „zwykłej” karty ryzyka SCORE (jak w przypadku klinicznym opisanym na końcu artykułu) albo - precyzyjniej — z zastosowaniem przeznaczonych do tego tabel (oddzielnych dla kobiet i mężczyzn, patrz tab. 1) [1].

Obie powyższe metody umożliwiają identyfikację tych osób, które mimo niskiego lub umiarkowanego 10-letniego ryzyka bezwzględnego ocenionego za pomoca "zwykłej” skali SCORE zagrożone są, przy braku odpowiednich działań prewencyjnych, wystąpieniem CVD w późniejszym okresie życia. O ile ocena ryzyka względnego możliwa jest dla osób w każdym wieku (także poniżej 40. rż.), to karty wieku serca są przeznaczone (podobnie jak „zwykłe” karty SCORE) dla osób w wieku 40-65 lat. Niezaprzeczalnym atutem oceny wieku naczyń jest jednak możliwość obrazowego i przemawiającego do wyobraźni przedstawienia pacjentowi aktualnego poziomu jego ryzyka sercowo-naczyniowego i związanego z nim prawdopodobnego skrócenia długości życia. Porównanie pacjenta 50-letniego z 60- czy 70-latkiem może zadziałać bardziej motywująco niż opisanie jego 10-letniego ryzyka zgonu z powodu CVD jako kilku-czy kilkunastoprocentowego. W porównaniu ze „zwykłą” kartą SCORE inną zaletą karty wieku serca jest możliwość jej stosowania w każdej populacji bez konieczności dokonywania kalibracji [1]

\section{WPLYW PROCESU STARZENIA \\ NA STRUKTURĘ I FUNKCJĘ NACZYŃ}

Patogenetycznym podłożem CVD jest miażdżyca będąca przewlekłym procesem zapalno-immunologiczno-degeneracyjnym zajmującym tętnice małego i średniego kalibru. Jej rozwój cechuje się bardzo zróżnicowaną etio- patogenezą i dynamiką. Postępujący wiek, niezależnie od innych czynników ryzyka, prowadzi do biochemicznych, histologicznych i strukturalnych zmian w obrębie naczyń, co sprzyja procesom prozapalnym oraz progresji i destabilizacji blaszek miażdżycowych [3, 8]. Zmiany zachodzące w obrębie naczynia wraz z procesem starzenia przedstawiono na rycinie 1 .

Wraz z wiekiem człowieka dochodzi u niego do degeneracyjnych zmian elementów sprężystych i mięśni gładkich, inwersji stosunku elastyna-kolagen oraz nadmiernej sztywności tętnic $[9,10]$. Sztywność tętnic skutkuje wzrostem prędkości fali tętna (PWV, pulse wave velocity) i jej amplitudy. W rezultacie odbita od tętniczek oporowych, cofająca się fala tętna szybciej dociera do serca (jeszcze w okresie skurczu), zwiększając obciążenie następcze lewej komory i skurczowe ciśnienie tętnicze. Brak fizjologicznego powrotu fali tętna w fazie rozkurczu powoduje spadek ciśnienia rozkurczowego i przepływu wieńcowego oraz wzrost skurczowo-rozkurczowej amplitudy ciśnienia tętniczego - ciśnienia tętna. W wyniku wzrostu obciążenia następczego dochodzi do przerostu mięśnia sercowego i dalszego spadku przepływu wieńcowego. Sztywność naczyń jest czynnikiem patogenetycznym nadciśnienia tętniczego (a zwłaszcza izolowanego nadciśnienia skurczowego charakterystycznego dla osób w podeszłym wieku), choroby wieńcowej, przerostu mięśnia lewej komory i niewydolności serca, natomiast wartość PWV, jako „złoty standard” oceny sztywności tętnic, może wpływać na zmianę rokowania sercowo-naczyniowego [10-12].

Tlenek azotu (NO, nitric oxide) powstaje w warunkach fizjologicznych dzięki śródbłonkowej syntazie NO pod wpływem mediatorów neurohormonalnych, takich jak acetylocholina (ACh). Rola NO polega przede wszystkim na oddziaływaniu na mięśnie gładkie naczyń, a tym samym spełnianiu funkcji wazodylatacyjnej i przeciwzakrzepowej. Wraz z wiekiem człowieka dochodzi u niego do zmniejszania się biodostępności NO i jego zwiększonej biodegradacji [13]. Wyniki badań doświadczalnych wykazały, że starszy wiek i inne klasyczne czynniki ryzyka są niezależnymi predyktorami wazokonstrykcyjnej odpowiedzi tętnic wieńcowych na infuzję ACh (ACh wykazuje bezpośrednie działanie naczynioskurczowe oraz - przeważające $\mathrm{w}$ warunkach fizjologicznych - pośrednie działanie wazodylatacyjne związane ze zwiększeniem syntezy NO przez śródbłonek) [14]. Zaburzenia syntezy i aktywności NO zapoczątkowują proces tworzenia blaszki miażdżycowej. Równocześnie 
Tabela 1A. Tabela służąca do oszacowania wieku ryzyka sercowo-naczyniowego u kobiet. Liczby w tabeli oznaczają wiek ryzyka (opracowano na podstawie [1], zmodyfikowane)

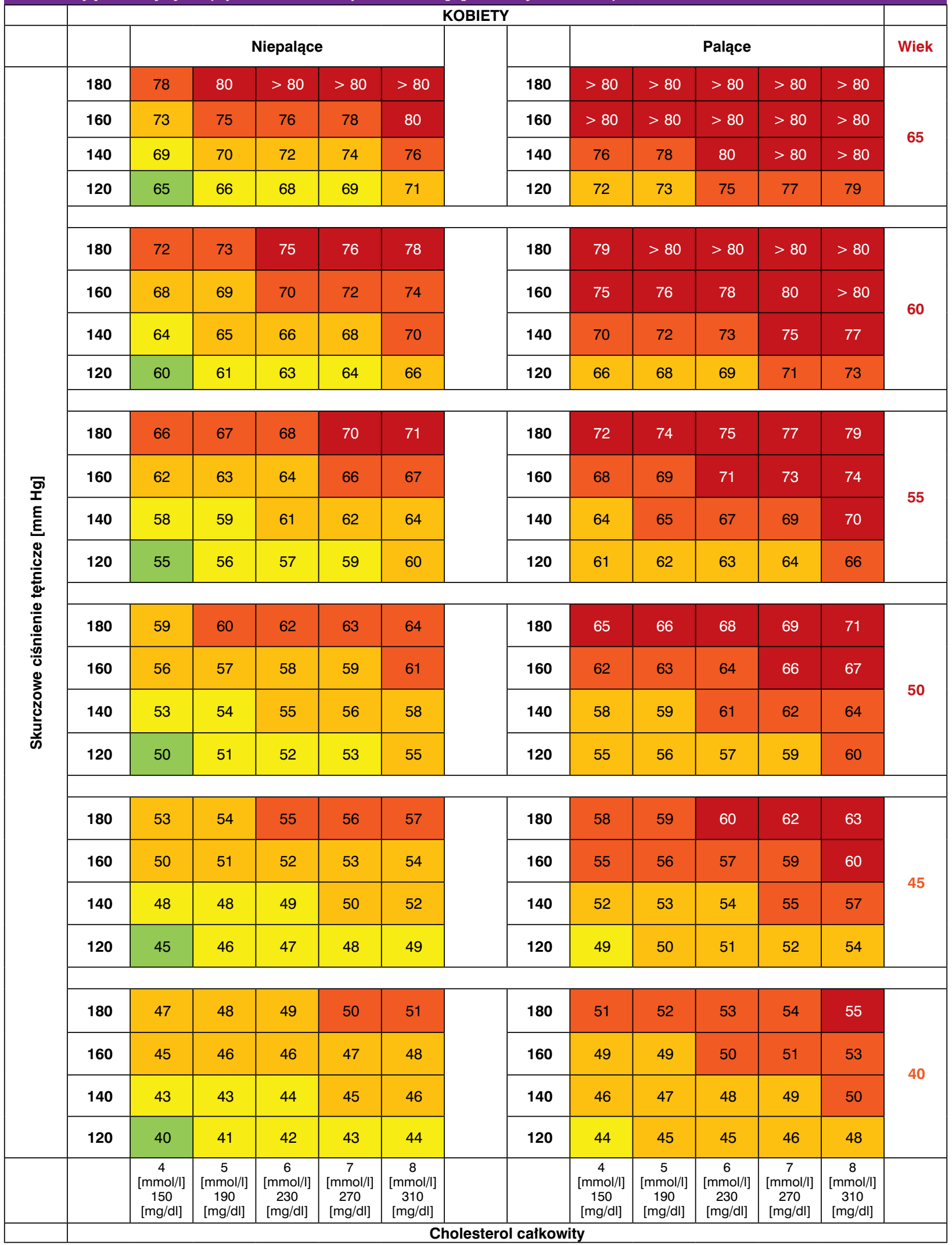


Tabela 1B. Tabela służąca do oszacowania wieku ryzyka sercowo-naczyniowego mężczyzn. Liczby w tabeli oznaczają wiek ryzyka (opracowano na podstawie [1], zmodyfikowane)

\begin{tabular}{|c|c|c|c|c|c|c|c|c|c|c|c|c|c|}
\hline & \multicolumn{12}{|c|}{ MĘŻCZYŹNI } & \multirow[b]{2}{*}{ Wiek } \\
\hline & & \multicolumn{5}{|c|}{ Niepalący } & & \multicolumn{5}{|c|}{ Palący } & \\
\hline \multirow{24}{*}{ 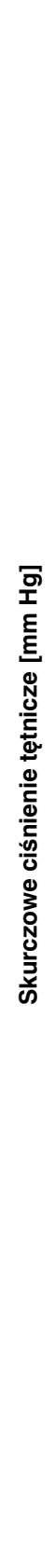 } & 180 & $>80$ & $>80$ & $>80$ & $>80$ & $>80$ & 180 & $>80$ & $>80$ & $>80$ & $>80$ & $>80$ & \multirow{4}{*}{65} \\
\hline & 160 & 76 & 79 & $>80$ & $>80$ & $>80$ & 160 & $>80$ & $>80$ & $>80$ & $>80$ & $>80$ & \\
\hline & 140 & 70 & 73 & 75 & 78 & $>80$ & 140 & $>80$ & $>80$ & $>80$ & $>80$ & $>80$ & \\
\hline & 120 & 65 & 67 & 70 & 72 & 75 & 120 & 75 & 77 & $>80$ & $>80$ & $>80$ & \\
\hline & 180 & 76 & 78 & $>80$ & $>80$ & $>80$ & 180 & $>80$ & $>80$ & $>80$ & $>80$ & $>80$ & \multirow{4}{*}{60} \\
\hline & 160 & 70 & 72 & 75 & 78 & 80 & 160 & 80 & $>80$ & $>80$ & $>80$ & $>80$ & \\
\hline & 140 & 65 & 67 & 69 & 72 & 75 & 140 & 74 & 77 & 80 & $>80$ & $>80$ & \\
\hline & 120 & 60 & 62 & 64 & 67 & 69 & 120 & 69 & 71 & 74 & 77 & 80 & \\
\hline & 180 & 69 & 71 & 74 & 76 & 79 & 180 & 79 & $>80$ & $>80$ & $>80$ & $>80$ & \multirow{4}{*}{55} \\
\hline & 160 & 64 & 66 & 68 & 71 & 74 & 160 & 73 & 76 & 79 & $>80$ & $>80$ & \\
\hline & 140 & 59 & 61 & 63 & 66 & 68 & 140 & 68 & 70 & 73 & 76 & 79 & \\
\hline & 120 & 55 & 57 & 59 & 61 & 64 & 120 & 63 & 65 & 68 & 70 & 73 & \\
\hline & 180 & 62 & 64 & 67 & 69 & 72 & 180 & 71 & 74 & 77 & 80 & $>80$ & \multirow{4}{*}{50} \\
\hline & 160 & 58 & 60 & 62 & 64 & 67 & 160 & 66 & 68 & 71 & 74 & 77 & \\
\hline & 140 & 54 & 56 & 58 & 60 & 62 & 140 & 61 & 64 & 66 & 68 & 71 & \\
\hline & 120 & 50 & 52 & 54 & 56 & 58 & 120 & 57 & 59 & 61 & 64 & 66 & \\
\hline & 180 & 56 & 58 & 60 & 62 & 64 & 180 & 64 & 66 & 68 & 71 & 74 & \multirow{4}{*}{45} \\
\hline & 160 & 52 & 54 & 55 & 57 & 60 & 160 & 59 & 61 & 63 & 66 & 68 & \\
\hline & 140 & 48 & 50 & 52 & 54 & 56 & 140 & 55 & 57 & 59 & 61 & 64 & \\
\hline & 120 & 45 & 47 & 48 & 50 & 53 & 120 & 51 & 53 & 55 & 57 & 59 & \\
\hline & 180 & 49 & 51 & 52 & 54 & 56 & 180 & 56 & 58 & 60 & 62 & 65 & \multirow{4}{*}{40} \\
\hline & 160 & 46 & 47 & 49 & 51 & 53 & 160 & 52 & 54 & 56 & 58 & 60 & \\
\hline & 140 & 43 & 44 & 46 & 47 & 49 & 140 & 48 & 50 & 52 & 54 & 56 & \\
\hline & 120 & 40 & 41 & 43 & 44 & 46 & 120 & 45 & 47 & 49 & 51 & 52 & \\
\hline & & $\begin{array}{c}4 \\
{[\mathrm{mmol} / \mathrm{l}]} \\
150 \\
{[\mathrm{mg} / \mathrm{dl}]}\end{array}$ & $\begin{array}{c}5 \\
{[\mathrm{mmol} / \mathrm{l}]} \\
190 \\
{[\mathrm{mg} / \mathrm{dl}]}\end{array}$ & $\begin{array}{c}6 \\
{[\mathrm{mmol} / \mathrm{l}]} \\
230 \\
{[\mathrm{mg} / \mathrm{dl}]}\end{array}$ & $\begin{array}{c}7 \\
{[\mathrm{mmol} / \mathrm{l}]} \\
270 \\
{[\mathrm{mg} / \mathrm{dl}]}\end{array}$ & $\begin{array}{c}8 \\
{[\mathrm{mmol} / \mathrm{l}]} \\
310 \\
{[\mathrm{mg} / \mathrm{dll}]}\end{array}$ & & $\begin{array}{c}4 \\
{[\mathrm{mmol} / \mathrm{l}]} \\
150 \\
{[\mathrm{mg} / \mathrm{dl}]}\end{array}$ & $\begin{array}{c}5 \\
{[\mathrm{mmol} / \mathrm{l}]} \\
190 \\
{[\mathrm{mg} / \mathrm{dll}]}\end{array}$ & $\begin{array}{c}6 \\
{[\mathrm{mmol} / \mathrm{l}]} \\
230 \\
{[\mathrm{mg} / \mathrm{dl}]}\end{array}$ & $\begin{array}{c}7 \\
{[\mathrm{mmol} / \mathrm{l}]} \\
270 \\
{[\mathrm{mg} / \mathrm{dl}]}\end{array}$ & $\begin{array}{c}8 \\
{[\mathrm{mmol} / \mathrm{l}]} \\
310 \\
{[\mathrm{mg} / \mathrm{dl}]}\end{array}$ & \\
\hline & \multicolumn{13}{|c|}{ terol całkowity } \\
\hline
\end{tabular}

Wiek ryzyka sercowo-naczyniowego wyższy od wieku metrykalnego o:

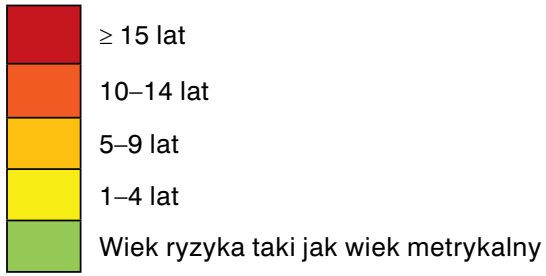




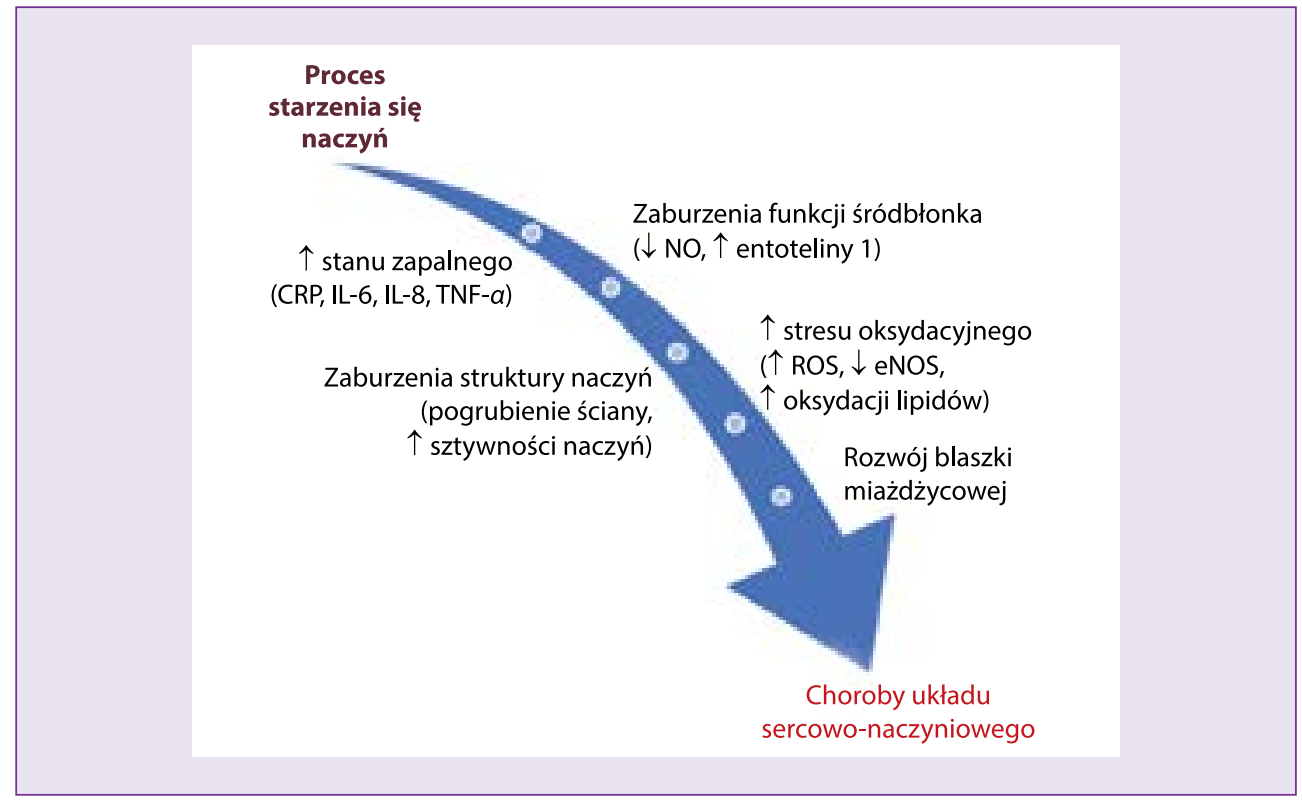

Rycina 1. Wpływ procesu starzenia na strukturę i funkcję naczyń; CRP (C-reactive protein) - białko C-reaktywne; IL-6 — interleukina 6; IL-8 -interleukina 8; TNF- $\alpha$ (tumour necrosis factor alpha) — czynnik martwicy nowotworów alfa; NO (nitric oxide) - tlenek azotu; ROS (reactive oxygen species) - reaktywne formy tlenu; eNOS (endothelial nitric oxide synthase) — śródbłonkowa syntaza tlenku azotu

z wiekiem człowieka zwiększa się natomiast produkcja endoteliny 1, czynnika charakteryzującego się właściwościami wazokonstrykcyjnymi, prozapalnymi i nasilającymi stres oksydacyjny [15].

W patogenezie miażdżycy podkreśla się rolę procesu zapalnego. Wzrost stężenia białek i cytokin prozapalnych następuje z wiekiem $[16,17]$. Jednocześnie w procesie starzenia istotne znaczenie dla rozwoju miażdżycy mają stres oksydacyjny i zależna od niego nadprodukcja wolnych rodników tlenowych oraz spadek stężenia glutationu $[18,19]$.

Wstępnym etapem rozwoju zmian miażdżycowych są zaburzenia funkcji śródbłonka związane z postępującym wiekiem, ale także z oddziaływaniem różnych czynników ryzyka, w tym tych ujętych w karcie ryzyka SCORE i karcie wieku ryzyka (nadciśnienie tętnicze, hipercholesterolemia, palenie tytoniu) [8]. Z wiekiem u człowieka dochodzi do pogrubienia błony wewnętrznej naczynia, co jest reakcją adaptacyjną na sily oddziałujące w obrębie naczynia, głównie naprężenia ścinające [20]. Strukturalnie naczynia stają się grubsze i mają większą średnicę. Pogrubienie błony wewnętrznej naczynia sprzyja utracie integralności komórek śródbłonka i w konsekwencji-zwiększonej migracji lipoprotein, monocytów i innych cząstek aterogennych do warstwy wewnętrznej ściany naczynia. Wzmożona produkcja białek adhezyjnych przyczynia się do ułatwienia migracji komórek [20-22]. W dalszej kolejności na skutek działania wolnych rodników dochodzi do powstania utlenionych form lipoprotein o małej gęstości (LDL, low-density lipoproteins), czyli oksy-LDL [13]. Następuje aktywacja makrofagów, które fagocytują zmodyfikowane formy LDL z udziałem „receptorów zmiatających" (SR, scavenger receptors), co powoduje ich przemianę $\mathrm{w}$ przeładowane cholesterolem komórki piankowate i patologiczne pogrubienie błony wewnętrznej naczynia. Tego typu zmiany, występujące głównie u osób młodych, nie zmniejszają światła naczynia i mogą ulec całkowitej regresji lub przejść w kolejne etapy zaawansowania [24]. Pod wpływem oksy-LDL są również aktywowane miocyty, które - przenikając do błony wewnętrznej naczynia produkują składowe tkanki łącznej, tworząc czapeczkę włóknistą chroniącą blaszkę miażdżycową przed pęknięciem. W rejonie powstałej blaszki miażdżycowej dochodzi do zaburzenia laminarnego przepływu krwi, co sprzyja dalszemu wzrostowi blaszki, a także jej destabilizacji poprzez aktywację komórek wytwarzających cytokiny zapalne i metaloproteinazy [10,13, 23-25].

Opisane powyżej zmiany związane $\mathrm{z}$ wiekiem zachodzą $w$ układzie naczyniowym $\mathrm{z}$ różnym nasileniem i dynamiką, a także zależą między innymi od wspólistnienia klasycznych czynników ryzyka miażdżycy, takich jak te ujęte w karcie ryzyka SCORE i karcie wieku ryzyka. 
Wydaje się jednak, że, biorąc pod uwagę zróżnicowaną osobniczo podatność tętnic na rozwój miażdżycy, wiek $\mathrm{i}$ inne tradycyjne czynniki ryzyka, mogą one nie w pełni odpowiadać za ryzyko CVD u danego pacjenta. Obecnie dostępne są takie nieinwazyjne markery wczesnych zmian w ścianie tętnic, jak grubość kompleksu intima-media (IMT, intima-media thickness), PWV, wskaźnik uwapnienia tętnic wieńcowych (calcium score) czy markery dysfunkcji śródbłonka [1,26-30]. Mogą one być przydatne w precyzyjniejszej ocenie ryzyka sercowo-naczyniowego danego pacjenta. Podstawowym narzędziem służącym do przeprowadzenia takiej oceny u osób bez jawnej CVD pozostaje jednak karta ryzyka SCORE.

\section{ZAHAMOWANIE PROGRESJI MIAŻDŻYCY}

Kluczową rolę w prewencji CVD odgrywa modyfikacja czynników ryzyka. Utrzymujący się wraz z wiekiem ich wysoki poziom prowadzi do gwałtownego wzrostu bezwzględnego ryzyka sercowo-naczyniowego. Eliminacja czynników, które uszkadzają śródbłonek, może zahamować niekorzystne zmiany strukturalne oraz poprawić funkcję naczyń krwionośnych. Podstawą redukcji ryzyka CVD jest zmiana stylu życia: zaprzestanie palenia tytoniu, zwiększenie aktywności fizycznej, zmniejszenie masy ciała oraz wdrożenie właściwych nawyków żywieniowych. W znakomitej większości przypadków samo prowadzenie zdrowego stylu życia nie wystarcza, aby obniżyć ryzyko CVD do pożądanego poziomu. Jeżeli to konieczne, $\mathrm{w}$ dalszym etapie leczenia należy wdrożyć farmakoterapię w celu redukcji ciśnienia tętniczego czy stężenia cholesterolu frakcji LDL $[1,31,32]$. Lekami, które w bezpośredni sposób mogą zahamować progresję procesu miażdżycowego, a nawet częściowo go odwrócić, są statyny.

\section{STATYNY A RYZYKO SERCOWO-NACZYNIOWE}

Z ogólnopolskiego badania NATPOL 2011 wynika, że jedynie 8\% Polaków jest leczonych skutecznie z powodu dyslipidemii [33]. Leczenie zaburzeń lipidowych za pomocą statyn ma udowodnioną skuteczność w zmniejszaniu chorobowości i umieralności z przyczyn sercowo-naczyniowych, zarówno w ramach prewencji pierwotnej, jak i wtórnej [34-38]. Im większa redukcja stężenia cholesterolu frakcji LDL, tym mniejsze ryzyko incydentów sercowo-naczyniowych. W metaanalizie Cholesterol Treatment Trialists', przeprowadzonej $\mathrm{w}$ grupie ponad 170 tys. pacjentów, zmniejszenie stężenia cholesterolu frakcji LDL o każde 1,0 mmol/l (ok. $40 \mathrm{mg} / \mathrm{dl}$ ) wiązało się z ograniczeniem: 1) śmiertelności ogólnej o 10\%;2) śmiertelności z powodu choroby wieńcowej o $20 \%$; 3) częstości zdarzeń wieńcowych o $23 \%$ i 4) ryzyka udaru mózgu o 17\% [39].

W wytycznych ESC dotyczących zaburzeń lipidowych z 2016 roku ustalono nowe cele terapeutyczne w zakresie cholesterolu frakcji LDL dla pacjentów wysokiego i bardzo wysokiego ryzyka sercowo-naczyniowego rozpoczynających terapię hipolipemizującą: należy dążyć do co najmniej 50-procentowego obniżenia stężenia cholesterolu frakcji LDL, jeżeli jego wyjściowe stężenie wynosi między 100 a 200 mg/dl (ryzyko wysokie) lub między 70 a $135 \mathrm{mg} / \mathrm{dl}$ (ryzyko bardzo wysokie) [31]. Co więcej, zgodnie z aktualnym stanowiskiem Sekcji Farmakoterapii Sercowo-Naczyniowej Polskiego Towarzystwa Kardiologicznego, przedstawionym w III Deklaracji Sopockiej, chorzy z grup bardzo wysokiego i ekstremalnie wysokiego ryzyka sercowo-naczyniowego powinni osiągnąc stężenia cholesterolu frakcji LDL odpowiednio poniżej $55 \mathrm{mg} / \mathrm{dl}$ lub mniej niż $35 \mathrm{mg} / \mathrm{dl}$ [32]. Zatem u znacznej liczby pacjentów, nawet $w$ przypadku stosunkowo niskiego wyjściowego stężenia cholesterolu frakcji LDL, należy dążyć do jego dalszego obniżenia o co najmniej 50\%. Tak dużą redukcję można osiągnąć jedynie poprzez zastosowanie tak zwanych silnych statyn - atorwastatyny lub rosuwastatyny. Co więcej, w opublikowanej niedawno metaanalizie, obejmującej dane ponad 94 tys. pacjentów, to właśnie te dwie statyny, stosowane $\mathrm{w}$ ramach prewencji pierwotnej, okazały się najskuteczniejsze w zakresie redukcji ryzyka incydentów sercowo-naczyniowych [38]. Jednocześnie atorwastatyna charakteryzowała się najlepszym profilem bezpieczeństwa [38].

Obniżenie ryzyka zdarzeń sercowo-naczyniowych pod wpływem terapii statynami jest pochodną nie tylko redukcji stężenia cholesterolu frakcji LDL, lecz także ich dodatkowych działań plejotropowych [31, 32, 40, 41]. Na rycinie 2 przedstawiono plejotropowe działanie statyn na przykładzie atorwastatyny. Zwiększa ona sekrecję i bioaktywność NO w komórkach śródbłonka oraz hamuje produkcję endoteliny, sprzyjając wazodylatacji [42]. Ponadto wykazuje działanie antyoksydacyjne i hamuje powstawanie utlenionych form cholesterolu (oksy-LDL), a w konsekwencji-komórek piankowatych [42]. Poprzez wpływ na mechanizmy odpowiedzi immunologicznej wykazuje efekt przeciwzapalny [40-44]. Wyniki badania MIRACL (Myocardial Ischemia Reduction with Aggressive Cholesterol Lowering) dowiodły, że atorwastatyna zmniejsza stężenie białka C-reaktywnego (CRP, C-reactive protein) i innych cytokin prozapalnych [45]. Powoduje również spadek aktywności cząsteczek 


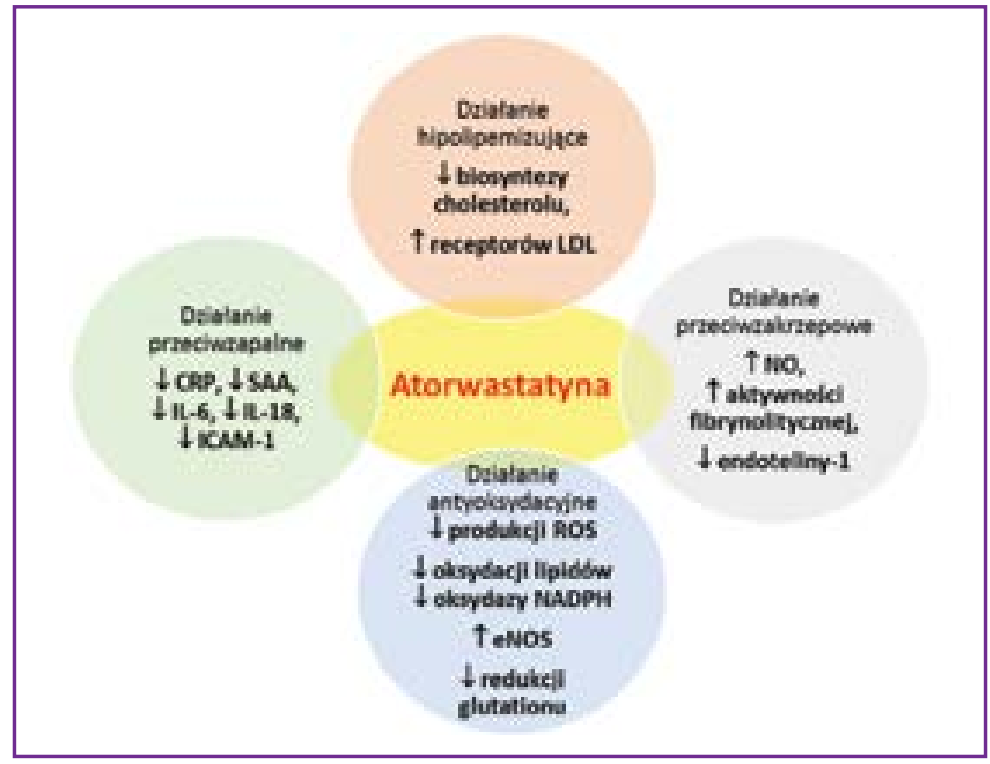

Rycina 2. Plejotropowe działanie atorwastatyny; LDL (low-density lipoproteins) — lipoproteiny o małej gęstości; CRP (C-reactive protein) - białko C-reaktywne; SAA (serum amyloid A) - surowiczy amyloid A; IL-6 - interleukina 6; IL-8 - interleukina 8; ICAM-1 (intercellular cell adhesion molecule 1) - cząsteczka adhezji międzykomórkowej 1; NO (nitric oxide) - tlenek azotu; ROS (reactive oxygen species) - reaktywne formy tlenu; NADPH (reduced nicotinamide adenine dinucleotide phosphate) — zredukowany fosforan dinukleotydu nikotynamidoadeninowego; eNOS (endothelial nitric oxide synthase) — śródbłonkowa syntaza tlenku azotu

adhezyjnych i zmniejszenie stężenia metaloproteinaz. Wszystkie powyższe procesy prowadzą do stabilizacji blaszki miażdżycowej [41,42-46]. Atorwastatyna zmniejsza sztywność naczyń krwionośnych także u osób bez hipercholesterolemii. Ponadto udowodniono korzystny wpływ atorwastatyny na układ krzepnięcia $[41,45,46]$.

\section{PRZYPADEK KLINICZNY}

W przypadku 40-letniego palącego papierosy mężczyzny, z wartościami skurczowego ciśnienia tętniczego $180 \mathrm{~mm} \mathrm{Hg}$ oraz ze stężeniem cholesterolu całkowitego wynoszącym $270 \mathrm{mg} / \mathrm{dl}(7 \mathrm{mmol} / \mathrm{l})$, na podstawie karty ryzyka SCORE całkowite ryzyko sercowo-naczyniowe można ocenić jako umiarkowane (3-proc. ryzyko zgonu z powodu CVD w ciągu najbliższych 10 lat, patrz tab. 2). Taki wynik może się nie wydawać alarmujący i mógłby skłonić do tego, aby opóźnić wdrożenie intensywnej terapii czynników ryzyka. Mimo tego ocena wieku ryzyka (inaczej: wieku serca, wieku naczyń) u tego chorego ujawnia istotnie podwyższone ryzyko względne:

- w tabeli 2 przedstawiono orientacyjną ocenę wieku naczyń za pomocą „zwykłej” karty ryzyka SCORE w tym przypadku wiek ryzyka wyniósł około 60 lat;

- na podstawie odpowiedniej skali (tab. 1) można precyzyjniej oszacować wiek serca - w tym przypadku wiek ryzyka wyniósł 62 lata;
- na rycinie 3 przedstawiono ocenę pacjenta dokonaną za pomocą obu powyższych skal z wykorzystaniem kalkulatora dostępnego online.

W omawianym przypadku wiek serca okazał się o ponad 20 lat wyższy od wieku metrykalnego, co skłoniło lekarza prowadzącego do intensyfikacji działań prewencyjnych. Oprócz zaleceń niefarmakologicznych (obejmujących zaprzestanie palenia tytoniu i zmianę diety) włączono leczenie hipotensyjne. Jednocześnie, mimo oszacowania całkowitego ryzyka CVD za pomocą karty SCORE jako umiarkowanego, biorąc pod uwagę obecność znacznie podwyższonego pojedynczego czynnika ryzyka (nadciśnienie tętnicze 3. stopnia) oraz istotnie podwyższony wiek naczyń, ryzyko sercowo-naczyniowe $\mathrm{u}$ tego chorego należy ocenić jako wysokie. Dlatego $\mathrm{w}$ tym przypadku oprócz postępowania dietetycznego trzeba niezwłocznie rozpocząć terapię statyną, dążąc do osiągnięcia co najmniej 50-procentowej redukcji stężenia cholesterolu frakcji LDL (wyjściowe stężenie cholesterolu frakcji LDL u tego chorego wynosiło $178 \mathrm{mg} / \mathrm{dl}$ ). Włączono leczenie atorwastatyną: początkowo w dawce $40 \mathrm{mg} /$ /dobę, a następnie w dawce $80 \mathrm{mg} /$ dobę, uzyskując redukcję stężenia cholesterolu frakcji LDL do $87 \mathrm{mg} / \mathrm{dl}$, a cholesterolu całkowitego — do $171 \mathrm{mg} / \mathrm{dl}$. Jednocześnie pod wpływem leczenia hipotensyjnego średnie wartości skurczowego ciśnienia tętniczego obniżyły się do $135 \mathrm{~mm} \mathrm{Hg}$. 
Tabela 2. Karta ryzyka SCORE (Systematic COronary Risk Evaluation) skalibrowana dla mężczyzn z krajów wysokiego ryzyka sercowo-naczyniowego, przedstawiająca, w jaki sposób można na jej podstawie odczytać wiek ryzyka. Liczby w tabeli oznaczają ryzyko zgonu z przyczyn sercowo-naczyniowych w ciągu 10 lat (opracowano na podstawie [1], zmodyfikowane)

\begin{tabular}{|c|c|c|c|c|c|c|c|c|c|c|c|c|c|}
\hline & \multicolumn{12}{|c|}{ MĘŻCZYŹ́NI } & \multirow[b]{2}{*}{ Wiek } \\
\hline \multirow{21}{*}{ 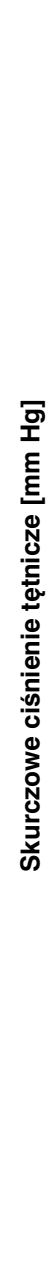 } & & \multicolumn{5}{|c|}{ Niepalący } & & \multicolumn{5}{|c|}{ Palący } & \\
\hline & 180 & 14 & 16 & 19 & 22 & 26 & 180 & 26 & 30 & 35 & 41 & 47 & \multirow{4}{*}{65} \\
\hline & 160 & 9 & 11 & 13 & 15 & 16 & 160 & 18 & 21 & 25 & 29 & 34 & \\
\hline & 140 & 6 & 8 & 9 & 11 & 13 & 140 & 13 & 15 & 17 & 20 & 24 & \\
\hline & 120 & 4 & 5 & 6 & 7 & 9 & 120 & 9 & 10 & 12 & 14 & 17 & \\
\hline & 180 & 9 & 11 & 13 & 15 & 18 & 180 & 18 & 21 & 24 & 28 & 33 & \multirow{4}{*}{60} \\
\hline & 160 & 6 & 7 & 9 & 10 & 12 & 160 & 12 & 14 & 17 & 20 & 24 & \\
\hline & 140 & 4 & 5 & 6 & 7 & 9 & 140 & 8 & 10 & 12 & 14 & 17 & \\
\hline & 120 & 3 & 3 & 4 & 5 & 6 & 120 & 6 & 7 & 8 & 10 & 12 & \\
\hline & 180 & 6 & 7 & 8 & 10 & 12 & 180 & 12 & 13 & 16 & 19 & 22 & \multirow{4}{*}{55} \\
\hline & 160 & 4 & 5 & 6 & 7 & 8 & 160 & 8 & 9 & 11 & 13 & 16 & \\
\hline & 140 & 3 & 3 & 4 & 5 & 6 & 140 & 5 & 6 & 8 & 9 & 11 & \\
\hline & 120 & 2 & 2 & 3 & 3 & 4 & 120 & 4 & 4 & 5 & 6 & 8 & \\
\hline & 180 & 4 & 4 & 5 & 6 & 7 & 180 & 7 & 8 & 10 & 12 & 14 & \multirow{4}{*}{50} \\
\hline & 160 & 2 & 3 & 3 & 4 & 5 & 160 & 5 & 6 & 7 & 8 & 10 & \\
\hline & 140 & 2 & 2 & 2 & 3 & 3 & 140 & 3 & 4 & 5 & 6 & 7 & \\
\hline & 120 & 1 & 1 & 2 & 2 & 2 & 120 & 2 & 3 & 3 & 4 & 5 & \\
\hline & 180 & 1 & 1 & 1 & 2 & 2 & 180 & 2 & 2 & 3 & 3 & 4 & \multirow{4}{*}{40} \\
\hline & 160 & 1 & 1 & 1 & 1 & 1 & 160 & 1 & 2 & 2 & 2 & 3 & \\
\hline & 140 & 0 & 1 & 1 & 1 & 1 & 140 & 1 & 1 & 1 & 2 & 2 & \\
\hline & 120 & 0 & 0 & 1 & 1 & 1 & 120 & 1 & 1 & 1 & 1 & 1 & \\
\hline & & $\begin{array}{c}4 \\
{[\mathrm{mmol} / \mathrm{ll}]} \\
150 \\
{[\mathrm{mg} / \mathrm{dll}]}\end{array}$ & $\begin{array}{c}5 \\
{[\mathrm{mmol} / 1]} \\
190 \\
{[\mathrm{mg} / \mathrm{dl}]}\end{array}$ & $\begin{array}{c}6 \\
{[\mathrm{mmol} / \mathrm{l}]} \\
230 \\
{[\mathrm{mg} / \mathrm{dll}]}\end{array}$ & $\begin{array}{c}7 \\
{[\mathrm{mmol} / \mathrm{l}]} \\
270 \\
{[\mathrm{mg} / \mathrm{dll}]}\end{array}$ & $\begin{array}{c}8 \\
{[\mathrm{mmol} / \mathrm{l}]} \\
310 \\
{[\mathrm{mg} / \mathrm{dl}]}\end{array}$ & & $\begin{array}{c}4 \\
{[\mathrm{mmol} / \mathrm{l}]} \\
150 \\
{[\mathrm{mg} / \mathrm{dll}]}\end{array}$ & $\begin{array}{c}5 \\
{[\mathrm{mmol} / \mathrm{l}]} \\
190 \\
{[\mathrm{mg} / \mathrm{dll}]}\end{array}$ & $\begin{array}{c}6 \\
{[\mathrm{mmol} / \mathrm{l}]} \\
230 \\
{[\mathrm{mg} / \mathrm{dll}]}\end{array}$ & $\begin{array}{c}7 \\
{[\mathrm{mmol} / \mathrm{l}]} \\
270 \\
{[\mathrm{mg} / \mathrm{dll}]}\end{array}$ & $\begin{array}{c}8 \\
{[\mathrm{mmol} / \mathrm{l}]} \\
310 \\
{[\mathrm{mg} / \mathrm{dl}]}\end{array}$ & \\
\hline & \multicolumn{13}{|c|}{ erol całkowity } \\
\hline
\end{tabular}

10-letnie ryzyko zgonu sercowo-naczyniowego:

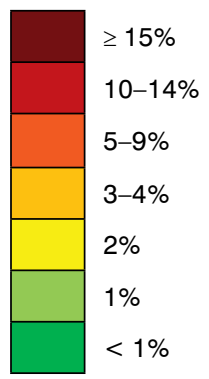

W omawianym przypadku 40-letniego palącego mężczyzny ze źle kontrolowanym nadciśnieniem tętniczym i hipercholesterolemią ryzyko sercowo-naczyniowe jest takie samo (3\%) jak u 60-letniego mężczyzny z idealnie wyrównanymi czynnikami ryzyka, dlatego w tym przypadku wiek ryzyka (wiek naczyń) wynosi ok. 60 lat

W ten sposób wiek ryzyka u tego chorego obniżył się do 50 lat. Zaprzestanie palenia i dalsza redukcja wartości ciśnienia tętniczego mogłyby doprowadzić do zbliżenia wieku ryzyka do wieku metrykalnego pacjenta.

\section{PODSUMOWANIE}

Karta wieku ryzyka sercowo-naczyniowego jest przydatnym narzędziem umożliwiającym dodatkową, precyzyjniejszą stratyfikację ryzyka rozwoju CVD, 


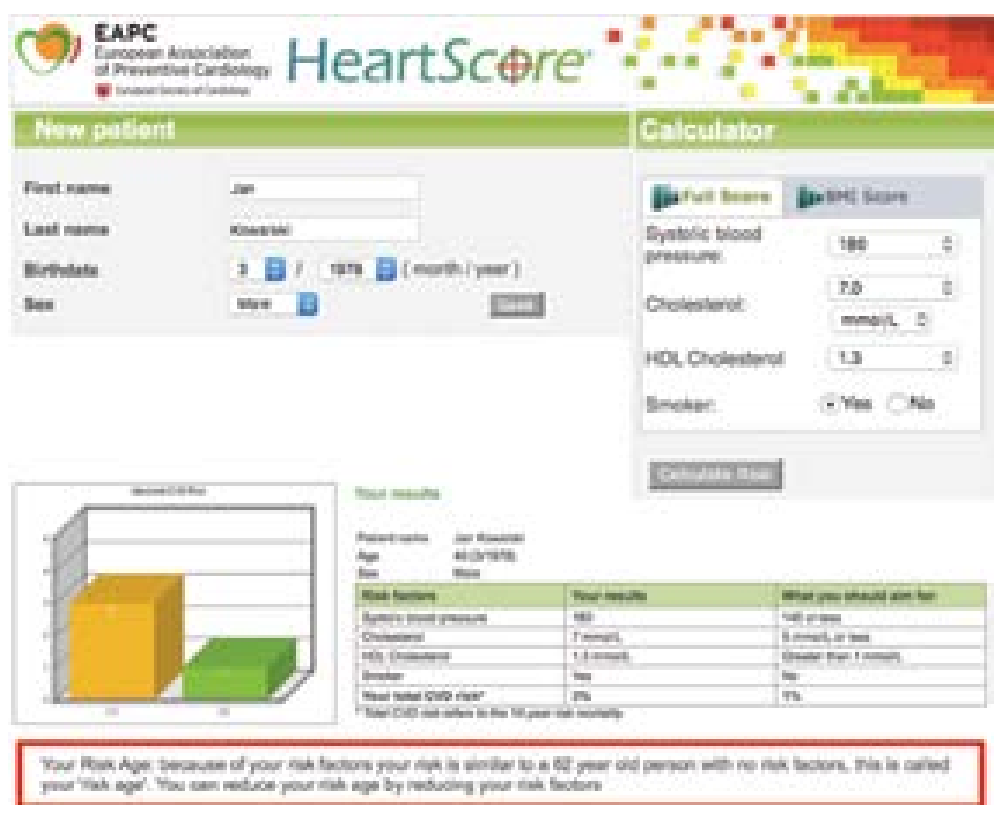

Rycina 3. Ocena wieku ryzyka oraz całkowitego ryzyka sercowo-naczyniowego na podstawie skali SCORE (Systematic COronary Risk Evaluation) u przykładowego pacjenta (imię i nazwisko zmienione) za pomocy kalkulatora dostępnego na www.heartscore.org

zwłaszcza u młodych osób, a jej zastosowanie może ułatwić komunikację i poprawić współpracę z pacjentem. W sytuacji, w której wiek ryzyka jest istotnie podwyższony w stosunku do wieku metrykalnego, należy wdrożyć intensywne działania prewencyjne obejmujące modyfikację czynników ryzyka. Statyny poprzez swoje funkcje plejotropowe pozwalają zahamować progresję miażdżycy, a ich stosowanie wiąże się ze zmniejszeniem ryzyka zdarzeń sercowo-naczyniowych także u osób bez stwierdzanej wyjściowo CVD.

\section{KONFLIKT INTERESÓW}

Agata Tymińska: honoraria za wykłady lub udział w badaniach klinicznych: Novartis, Boehringer Ingelheim.

Agnieszka Kapłon-Cieślicka: honoraria za wykłady, granty wyjazdowe lub udział w badaniach klinicznych: Abbott Laboratories, Bayer, Boehringer Ingelheim, Boston Scientific, Krka, MSD, Pfizer, Sandoz, Servier, Viventum.

\section{PIŚMIENNICTWO}

1. Piepoli MF, Hoes AW, Agewall S, et al. Authors/Task Force Members: Authors/Task Force Members, Additional Contributor: Simone Binno (Italy), Document Reviewers: ESC Scientific Document Group. 2016 European Guidelines on cardiovascular disease prevention in clinical practice: the Sixth Joint Task Force of the European Society of Cardiology and Other Societies on Cardiovascular Disease Prevention in Clinical Practice (constituted by representatives of 10 societies and by invited experts)Developed with the special contribution of the European Association for Cardiovascular Prevention \& Rehabilitation (EACPR). Eur Heart J. 2016; 37(29): 2315-2381, doi: 10.1093/eurheartj/ehw106, indexed in Pubmed: 27222591.

2. Perk J, De Backer G, Gohlke H, et al. Comitato per Linee Guida Pratiche (CPG) dell'ESC, European Association for Cardiovascular Prevention \& Rehabilitation (EACPR), Fifth Joint Task Force of the European Society of Cardiology and Other Societies on Cardiovascular Disease Prevention in Clinical Practice, European Association for Cardiovascular Prevention and Rehabilitation, European Association for Cardiovascular Prevention \& Rehabilitation (EACPR), ESC Committee for Practice Guidelines (CPG). European Guidelines on cardiovascular disease prevention in clinical practice (version 2012). The Fifth Joint Task Force of the European Society of Cardiology and Other Societies on Cardiovascular Disease Prevention in Clinical Practice (constituted by representatives of nine societies and by invited experts). Eur Heart J. 2012; 33(13): 1635-1701, doi: 10.1093/eurheartj/ehs092, indexed in Pubmed: 22555213.

3. Zieske AW, Malcom GT, Strong JP. Natural history and risk factors of atherosclerosis in children and youth: the PDAY study. Pediatr Pathol Mol Med. 2002; 21(2): 213-237, doi: 10.1080/15227950252852104, indexed in Pubmed: 11942537.

4. Conroy RM, Pyörälä K, Fitzgerald AP, et al. SCORE project group. Estimation of ten-year risk of fatal cardiovascular disease in Europe: the SCORE project. Eur Heart J. 2003; 24(11): 987-1003, doi: 10.1016/ /s0195-668x(03)00114-3, indexed in Pubmed: 12788299.

5. D'Agostino RB, Vasan RS, Pencina MJ, et al. General cardiovascular risk profile for use in primary care: the Framingham Heart Study. Circulation. 2008; 117(6): 743-753, doi: 10.1161/CIRCULATIONAHA.107.699579, indexed in Pubmed: 18212285.

6. Zdrojewski T, Jankowski P, Bandosz $P$, et al. [A new version of cardiovascular risk assessment system and risk charts calibrated for Polish population]. Kardiol Pol. 2015; 73(10): 958-961, doi: 10.5603/ /KP.2015.0182, indexed in Pubmed: 26521843.

7. The Blood Pressure Lowering Treatment Trialists' Collaboration. Blood pressure-lowering treatment based on cardiovascular risk: a meta- 
-analysis of individual patient data. The Lancet. 2014: 384(9943): 591-598, doi: 10.1016/s0140-6736(14)61212-5.

8. Wang JC, Bennett M. Aging and atherosclerosis: mechanisms, functional consequences, and potential therapeutics for cellular senescence. Circ Res. 2012; 111(2): 245-259, doi: 10.1161/CIRCRESAHA.111.261388, indexed in Pubmed: 22773427.

9. Spina M, Garbisa S, Hinnie J, et al. Age-related changes in composition and mechanical properties of the tunica media of the upper thoracic human aorta. Arteriosclerosis. 1983; 3(1): 64-76, indexed in Pubmed: 6824497

10. Sun Z. Aging, arterial stiffness, and hypertension. Hypertension. 2015; 65(2): 252-256, doi: 10.1161/HYPERTENSIONAHA.114.03617, indexed in Pubmed: 25368028

11. Mitchell GF, Parise H, Benjamin EJ, et al. Changes in arterial stiffness and wave reflection with advancing age in healthy men and women: the Framingham Heart Study. Hypertension. 2004; 43(6): 1239-1245, doi: 10.1161/01.HYP.0000128420.01881.aa, indexed in Pubmed: 15123572

12. Toprak A, Reddy J, Chen W, et al. Relation of pulse pressure and arterial stiffness to concentric left ventricular hypertrophy in young men (from the Bogalusa Heart Study). Am J Cardiol. 2009; 103(7): 978-984, doi: 10.1016/. amjcard.2008.12.011, indexed in Pubmed: 19327426.

13. Gradinaru D, Borsa C, lonescu C, et al. Oxidized LDL and NO synthesis - biomarkers of endothelial dysfunction and ageing. Mech Ageing Dev. 2015; 151: 101-113, doi: 10.1016/j.mad.2015.03.003, indexed in Pubmed: 25804383.

14. Vita JA, Treasure CB, Nabel EG, et al. Coronary vasomotor response to acetylcholine relates to risk factors for coronary artery disease. Circulation. 1990; 81(2): 491-497, indexed in Pubmed: 2105174.

15. Thijssen DHJ, Rongen GA, van Dijk A, et al. Enhanced endothelin-1-mediated leg vascular tone in healthy older subjects. J Appl Physiol (1985). 2007; 103(3): 852-857, doi: 10.1152/japplphysiol.00357.2007, indexed in Pubmed: 17556493.

16. Iantorno M, Campia U, Di Daniele N, et al. Obesity, inflammation and endothelial dysfunction. J Biol Regul Homeost Agents. 2014; 28(2): 169-176, indexed in Pubmed: 25001649.

17. Franceschi C, Campisi J. Chronic inflammation (inflammaging) and its potential contribution to age-associated diseases. J Gerontol A Biol Sci Med Sci. 2014; 69 Suppl 1: S4-S9, doi: 10.1093/gerona/glu057, indexed in Pubmed: 24833586.

18. Stamler JS, Hausladen A. Oxidative modifications in nitrosative stress Nat Struct Biol. 1998; 5(4): 247-249, indexed in Pubmed: 9546208.

19. Förstermann U. Oxidative stress in vascular disease: causes, defense mechanisms and potential therapies. Nat Clin Pract Cardiovaso Med. 2008; 5(6): 338-349, doi: 10.1038/ncpcardio1211, indexed in Pubmed: 18461048

20. LiYSJ, Haga JH, Chien S. Molecular basis of the effects of shear stress on vascular endothelial cells. J Biomech. 2005; 38(10): 1949-1971, doi: 10.1016/j.jbiomech.2004.09.030, indexed in Pubmed: 16084198.

21. Wasilewski J, Kiljański T, Miszalski-Jamka K. [Role of shear stress and endothelial mechanotransduction in atherogenesis]. Kardiol Pol. 2011; 69(7): 717-720, indexed in Pubmed: 21769796.

22. Potter DR, van Teeffelen J, Vink $\mathrm{H}$, et al. Perturbed mechanotransduction by endothelial surface glycocalyx modification greatly impairs the arteriogenic process. Am J Physiol Heart Circ Physiol. 2015; 309(4): H711-H717, doi: 10.1152/ajpheart.00257.2015, indexed in Pubmed: 26071545.

23. Stein $Y$, Stein O. Does therapeutic intervention achieve slowing of progression or bona fide regression of atherosclerotic lesions? Arterioscler Thromb Vasc Biol. 2001; 21(2): 183-188, indexed in Pubmed: 11156850.

24. van Oostrom O, Velema E, Schoneveld AH, et al. Age-related changes in plaque composition: a study in patients suffering from carotid artery stenosis. Cardiovasc Pathol. 2005; 14(3): 126-134, doi: 10.1016/j. carpath.2005.03.002, indexed in Pubmed: 15914297
25. Grufman H, Schiopu A, Edsfeldt A, et al. Evidence for altered inflammatory and repair responses in symptomatic carotid plaques from elderly patients. Atherosclerosis. 2014; 237 (1): 177-182, doi: 10.1016/j. atherosclerosis.2014.08.042, indexed in Pubmed: 25240113.

26. O'Leary DH, Polak JF, Kronmal RA, et al. Carotid-artery intima and media thickness as a risk factor for myocardial infarction and stroke in older adults. Cardiovascular Health Study Collaborative Research Group. N Engl J Med. 1999; 340(1): 14-22, doi: 10.1056/ /NEJM199901073400103, indexed in Pubmed: 9878640.

27. Den Ruijter HM, Peters SAE, Anderson TJ, et al. Common carotid intima-media thickness measurements in cardiovascular risk prediction: a meta-analysis. JAMA. 2012; 308(8): 796-803, doi: 10.1001/ /jama.2012.9630, indexed in Pubmed: 22910757.

28. Vlachopoulos C, Aznaouridis K, Stefanadis C. Prediction of cardiovascular events and all-cause mortality with arterial stiffness: a systematic review and meta-analysis. J Am Coll Cardiol. 2010; 55(13): 1318-1327, doi: 10.1016/j.jacc.2009.10.061, indexed in Pubmed: 20338492.

29. Tinana A, Mintz GS, Weissman NJ. Volumetric intravascular ultrasound quantification of the amount of atherosclerosis and calcium in nonstenotic arterial segments. Am J Cardiol. 2002; 89(6): 757-760, indexed in Pubmed: 11897220.

30. Silber S. Comparison of spiral and electron beam tomography in the evaluation of coronary calcification in asymptomatic persons. Int J Cardiol. 2002; 82(3): 297-298; author reply 299, indexed in Pubmed: 11911919

31. Catapano AL, Graham I, De Backer G, et al. Additional Contributor, Authors/Task Force Members, ESC Scientific Document Group. 2016 ESC/EAS guidelines for the management of dyslipidaemias. Eur Heart J. 2016; 37(39): 2999-3058, doi: 10.1093/eurheartj/ehw272, indexed in Pubmed: 27567407.

32. Szymański FM, Barylski M, Cybulska B, et al. Recommendation for the management of dyslipidemia in Poland - Third Declaration of Sopot. Interdisciplinary Expert Position Statement endorsed by the Polish Cardiac Society Working Group on Cardiovascular Pharmacotherapy. Cardiol J. 2018; 25(6): 655-665, doi: 10.5603/CJ.2018.0141, indexed in Pubmed: 30600830.

33. Zdrojewski T, Solnica B, Cybulska B, et al. Prevalence of lipid abnormalities in Poland. The NATPOL 2011 survey. Kardiol Pol. 2016; 74(3): 213-223, doi: 10.5603/KP.2016.0029, indexed in Pubmed: 27004543.

34. Ray KK, Cannon CP, McCabe CH, et al. PROVE IT-TIMI 22 Investigators. Early and late benefits of high-dose atorvastatin in patients with acute coronary syndromes: results from the PROVE IT-TIMI 22 trial. J Am Coll Cardiol. 2005; 46(8): 1405-1410, doi: 10.1016/j.jacc.2005.03.077, indexed in Pubmed: 16226162.

35. Waters DD, Guyton JR, Herrington DM, et al. TNT Steering Committee Members and Investigators. Treating to New Targets (TNT) Study: does lowering low-density lipoprotein cholesterol levels below currently recommended guidelines yield incremental clinical benefit? Am J Cardiol. 2004; 93(2): 154-158, indexed in Pubmed: 14715339.

36. Colhoun HM, Betteridge DJ, Durrington PN, et al. CARDS Investigators. Primary prevention of cardiovascular disease with atorvastatin in type 2 diabetes in the Collaborative Atorvastatin Diabetes Study (CARDS): multicentre randomised placebo-controlled trial. Lancet. 2004; 364(9435): 685-696, doi: 10.1016/S0140-6736(04)16895-5, indexed in Pubmed: 15325833.

37. Sever PS, Dahlöf B, Poulter NR, et al. ASCOT Investigators, ASCOT investigators. Prevention of coronary and stroke events with atorvastatin in hypertensive patients who have average or lower-than-average cholesterol concentrations, in the Anglo-Scandinavian Cardiac Outcomes Trial — Lipid Lowering Arm (ASCOT-LLA): a multicentre randomised controlled trial. Lancet. 2003; 361 (9364): 1149-1158, doi: 10.1016/S0140-6736(03)12948-0, indexed in Pubmed: 12686036.

38. Yebyo HG, Aschmann HE, Kaufmann M, et al. Comparative effectiveness and safety of statins as a class and of specific statins for 
primary prevention of cardiovascular disease: a systematic review, meta-analysis, and network meta-analysis of randomized trials with 94,283 participants. Am Heart J. 2019; 210: 18-28, doi: 10.1016/j. ahj.2018.12.007, indexed in Pubmed: 30716508.

39. Mihaylova B, Emberson J, Blackwell L, et al. Cholesterol Treatment Trialists' (CTT) Collaborators. The effects of lowering LDL cholesterol with statin therapy in people at low risk of vascular disease: meta-analysis of individual data from 27 randomised trials. Lancet. 2012; 380(9841): 581-590, doi: 10.1016/S0140-6736(12)60367-5, indexed in Pubmed: 22607822.

40. Oesterle A, Laufs U, Liao JK. Pleiotropic Effects of Statins on the Cardiovascular System. Circ Res. 2017; 120(1): 229-243, doi: 10.1161/ /CIRCRESAHA.116.308537, indexed in Pubmed: 28057795.

41. Hoshiga M, Arishiro K, Nakakoji T, et al. Switching to aggressive statin improves vascular endothelial function in patients with stable coronary artery disease. J Atheroscler Thromb. 2010; 17(7): 705-711, indexed in Pubmed: 20065610.

42. Yamada Y, Takeuchi S, Yoneda M, et al. Atorvastatin reduces cardiac and adipose tissue inflammation in rats with metabolic syndrome Int J Cardiol. 2017; 240: 332-338, doi: 10.1016/j.ijcard.2017.04.103, indexed in Pubmed: 28499669.
43. Schirmer $\mathrm{SH}$, Werner $\mathrm{CM}$, Laufs $\mathrm{U}$, et al. Nitric oxide-donating statins: a new concept to boost the lipid-independent effects. Cardiovasc Res. 2012; 94(3): 395-397, doi: 10.1093/cvr/cvs148, indexed in Pubmed: 22499774.

44. Alber HF, Frick M, Süssenbacher A, et al. Effect of atorvastatin on peripheral endothelial function and systemic inflammatory markers in patients with stable coronary artery disease. Wien Med Wochenschr. 2007; 157(3-4): 73-78, doi: 10.1007/s10354-007-0377-y, indexed in Pubmed: 17340064.

45. Kinlay S, Schwartz GG, Olsson AG, et al. Myocardial Ischemia Reduction with Aggressive Cholesterol Lowering Study Investigators. High-dose atorvastatin enhances the decline in inflammatory markers in patients with acute coronary syndromes in the MIRACL study. Circulation. 2003; 108(13): 1560-1566, doi: 10.1161/01.CIR.0000091404.09558. AF, indexed in Pubmed: 12975259.

46. Xu X, Liu Yu, Li K, et al. Intensive atorvastatin improves endothelial function and decreases ADP-induced platelet aggregation in patients with STEMI undergoing primary $\mathrm{PCl}$ : A single-center randomized controlled trial. Int J Cardiol. 2016; 222: 467-472, doi: 10.1016/j.ijcard.2016.07.223, indexed in Pubmed: 27505335. 